\title{
Identity and distribution of the Nearctic otter (Lontra canadensis) at the Río Conchos Basin, Chihuahua, Mexico.
}

\author{
Juan Pablo Gallo-Reynoso ${ }^{1 *}$, Samuel Macías-Sánchez ${ }^{2}$, Veruschka A. Nuñez-Ramos ${ }^{3}$, Aron Loya-Jaquez ${ }^{3}$, Isai David Barba-Acuña ${ }^{1}$, lucila del \\ Carmen Armenta-Méndez ${ }^{1}$, Jimena J. Guerrero-Flores ${ }^{1}$, Gloria Ponce-García ${ }^{1}$, and Alfonso A. Gardea-Bejar ${ }^{1}$ \\ ${ }^{1}$ Centro de Investigación en Alimentación y Desarrollo A. C., Unidad Guaymas, Carretera al Varadero Nacional km 6.6, Las Playitas \\ CP. 85480, Guaymas. Sonora, México. Email: jpgallo@ciad.mx (JPG), isai.barba@ciad.mx (IDB), gloria.ponce.garcia@gmail.com \\ (GPG), lucila.armenta@gmail.com (LCA), gardea@ciad.mx (AGB), jimenag.sci@gmail.com (JGF). \\ ${ }^{2}$ Instituto de Biotecnología y Ecología Aplicada, Universidad Veracruzana, (Estudiante de doctorado), Avenida de las Culturas \\ Universitarias No. 101, Col. Emiliano Zapata, CP. 91090, Xalapa de Enríquez. Veracruz, México. Email: macsanch@yahoo.com (SMS). \\ ${ }^{3}$ Tennesse 1618. Residencial Campestre. CP. 31213, Chihuahua. Chihuahua, México. Email: veranhi78@hotmail.com (VNR), \\ aloya8@hotmail.com (ALJ). \\ *Corresponding author
}

We have identified a scarcely known river otter population from the Upper Río Conchos basin, northern Mexico, finding a well-established population of the Nearctic otter Lontra canadensis. A pioneer study of these otters at Río San Pedro, a tributary of the Río Conchos, described them as Neotropical otters, Lontra longicaudis; at that time, no specimens or photographs of these otters were available from the locality. Therefore, its taxonomic status remained unclear for various decades. Río Conchos is one of the major tributaries of Río Grande (Río Bravo in Mexico) and its headwaters are located high in the Sierra Madre Occidental. A juvenile otter fur obtained from Río San Pedro was compared to two furs of Neotropical otters from Oaxaca and Sonora, with the aim to compare the structure of primary hairs ( $\mathrm{PH})$ and secondary hairs (SH) in order to know their specific status. Camera traps were set-up at Río San Pedro in Chihuahua and in Arroyo Bamochi (occupied by L. longicaudis) in Sonora in 2015 to compare individuals, population structure and occupation in both places. Two other places were surveyed to confirm the presence of river otters: Río Conchos and Río Santa Isabel. Based on hair characteristics (primary and secondary hairs from the juvenile) and photographic evidence from camera-traps, we confirm that otters from Río San Pedro, belong to the Nearctic otter, Lontra canadensis. And presumably in other localities visited in the Concho's river basin that also has presence of otters, such as Río Santa Isabel and Río Conchos. The population structure from Arroyo Bamochi and Río San Pedro were similar in both areas, but the density of otters is higher at Arroyo Bamochi than at Río San Pedro, even though there is no significant difference between the two sites. Specimens of river otters from Río Grande basin have been identified as L. canadensis lataxina, Cuvier, 1823. The former distribution area of this species ranges from inland US across the Río Grande basin in the Rocky Mountains, the Río Pecos, further East, flowing south and southeast into the Gulf of Mexico. The finding reported here represents a major area occupied by this species, and a significant conservation issue for their protection in Mexico, as well as an indicator of the healthy conservation status of the upper Río Conchos.

Se identificó una población de nutria de río escasamente conocida de la cuenca alta del Río Conchos en el norte de México. Encontramos que la población está bien establecida y corresponde a la nutria Neártica, Lontra canadensis. Un estudio pionero de estas nutrias en el Río San Pedro, tributario del Río Conchos, las describió como nutria Neotropical, Lontra longicaudis; en ese tiempo no se conocía ningún espécimen o fotografías de nutrias de la localidad. Por lo que su estado taxonómico era poco claro, lo que duró varias décadas. El Río Conchos es uno de los mayores tributarios del Río Bravo (Río Grande en los Estados Unidos) y sus cabeceras se encuentran localizadas en la parte alta de la Sierra Madre Occidental. Se obtuvo la piel de una nutria juvenil del Río San Pedro, la cual fue comparada con dos pieles de nutria Neotropical, una de Oaxaca y otra de Sonora, para cotejar la estructura de los pelos primarios ( $\mathrm{PH}$ ) y de los pelos secundarios (SH) y determinar a qué especie pertenecía el individuo. Se colocaron cámaras trampa en el Río San Pedro en Chihuahua y en el Arroyo Bamochi (ocupado por L. longicaudis) en Sonora en el 2015, para comparar la estructura poblacional y la ocupación en ambos lugares. Otros dos lugares fueron visitados para confirmar la presencia de las nutrias, el: Río Conchos y el Río Santa Isabel. Con base en las características del pelo (pelos primarios y secundarios de la piel del juvenil) y evidencia fotográfica de las cámaras-trampa, confirmamos que las nutrias del Río San Pedro, Río Santa Isabel y del Río Conchos pertenecen a la especie Neártica: Lontra canadensis. La estructura de la población en el Arroyo Bamochi y en el Río San Pedro fueron similares en ambos sitios, pero la densidad de nutrias es más alta en el Arroyo Bamochi que en el Río San Pedro, aun así, no existe diferencia significativa entre los dos sitios. Los especímenes de nutrias de la Cuenca del Río Grande han sido identificados en el pasado como L. canadensis lataxina, Cuvier, 1823. La distribución original de esta especie va desde el interior de los Estados Unidos, a través de la Cuenca del Río Grande y del Río Pecos, de las montañas Rocallosas hacia el sur y sureste hacia el Golfo de México. El hallazgo reportado aquí representa un reto significativo para la conservación de esta especie en México, así como es un indicador del excelente estado de conservación del río.

Key Words: Chihuahua, Lontra canadensis, Mexico, Otter identity, Status.

๑) 2019 Asociación Mexicana de Mastozoología, www.mastozoologiamexicana.org

\section{Introduction}

Geographical barriers such as high mountain ranges have played a key role for the adaptation and evolution of numerous species whose populations were separated by catastrophic events, including volcanism, glaciations, and subsequent shifts in the flow direction of the major rivers. The rise of large mountain ranges resulting from plate tectonics at a continental scale has conformed impassable bar- 
riers for many species. On ecological time scales (thousands of years), these produced changes in local habitats, disruption of habitat connectivity and, over long periods of time, led to genetic differentiation, speciation and endemism. In addition, the distribution and occupancy of species are subject to selection pressures resulting from climatic gradients that affect habitat connectivity.

The high-elevation continental divide at Sierra Madre Occidental causes streams to flow in various directions to several large basins; these steep elevations are formidable geographical barriers that may be difficult for Neotropical otters to cross. This ancient steep-sloped and high-altitude mountain range rose around the Late Cretaceous ( 100 mya). Some deposits point to older ages, such as tuffs (volcanic igneous rocks composed mostly of compacted volcanic ash) near Cascada de Basaseachi (Basaseachi fall), which contain lithic fragments of granitic gneiss that are 1.6 billions of years old (Housh et al. 2003). Glaciations also formed large barriers that restrained the connection between eastern and western basins. Eight series of glaciations from 600-12 kya (Walker et al. 2008), likely shaped the current distribution of the genus Lontra in the Americas.

Climatic factors such as precipitation and temperature regimes (significantly colder winters), coupled with the occurrence of drier conditions in the eastern basin, may also have become a major barrier preventing connectivity between suitable habitats for Neotropical otters. This is due to the high mountain ridges with steep slopes and scarcity of running fresh water in the eastern slopes, along with different vegetation assemblages (pine-oak and tropical deciduous forest on the western slope vs. pine-oak and high-altitude grasslands and arid scrubland on the eastern side).

Therefore, geographical barriers imposed by the high mountain ranges or "Sierras" of México have confined the Neotropical otter (Lontra longicaudis) to the large river basins in the western slopes and coastal plains, rarely reaching the rivers running across the central plateau (Guerrero et al. 2015; see Figure 1). Therefore, it is unlikely the presence of Neotropical otters in both slopes of the continental divide in the Sierra Madre Occidental (i.e., the western slope down to the Gulf of California and the eastern slope down to the Central Plateau and Río Grande basin in northern Mexico) as suggested by Carrillo-Rubio and Lafón (2004). These authors have regarded otters found at Río San Pedro (Chihuahua) as Neotropical otters, although Polechla and Carrillo-Rubio (2009) later questioned their identity.

Nearctic otters, Lontra canadensis lataxina Cuvier, 1823, inhabit the basin of Río Grande that ranges from Colorado and New Mexico down to the Gulf of México (Hall 1981), these otters were declared, "apparently extirpated" (Findley et al. 1975; Jones and Schmitt 1997; Polechla et al. 2004; Polechla and Carrillo-Rubio 2009) due to hunting and habitat degradation. To counter this extirpation, 23 Nearctic otters were reintroduced to the Río Grande watershed in New Mexico in 2008 (Long 2010).

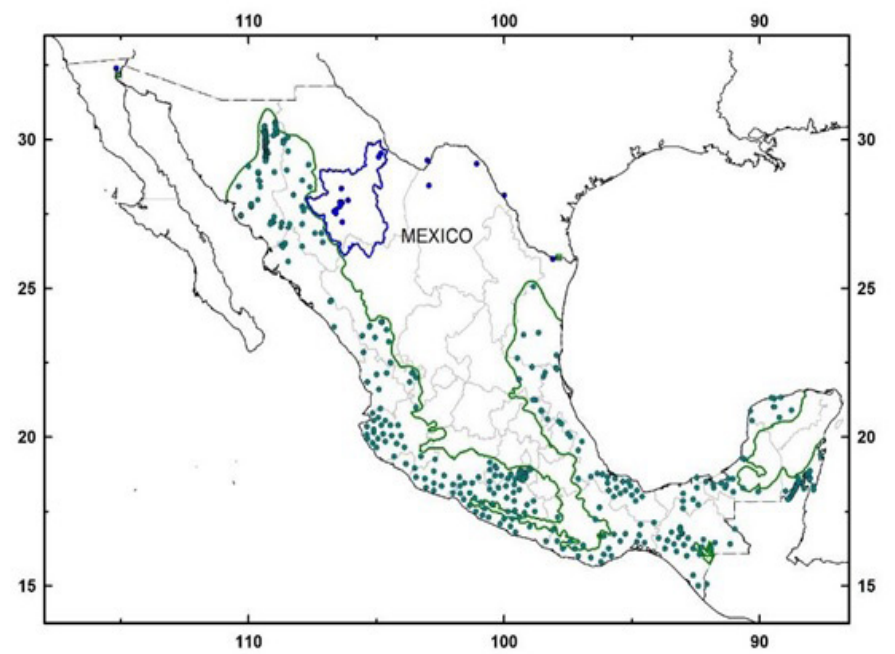

Figure 1. Current distribution of the Neotropical otter (Lontra longicaudis) (green dots and lines); and our records of a relict population of Nearctic otter (Lontra canadensis) in the Conchos basin, north-western Mexico (blue dots and blue line). Other records of $L$. canadensis in México, also in blue dots. Historic records of $L$. canadensis in green squares.

The Upper Río Conchos basin includes the Río San Pedro, Río San Lorenzo, Río Santa Isabel, Río Satevó, Río Chuviscar, Río Balleza and Río Florido, as well as other minor tributaries (such as Río Parral). This basin is located on the eastern slope of the Sierra Madre Occidental and drains into the high-altitude Central Plateau of Northern México, crossing the Chihuahuan desert towards its confluence with Río Grande to drain into the Gulf of México. There are four records of museum specimens and two recent records of this species from the 1980s in different sites along Río Grande which conforms the border between the United States and México and from affluents from México (Hall 1981; Gallo-Reynoso 1997; López-Wilchis 1998).

Based on the above logic, it is unlikely that the otter population reported here belongs to the Neotropical species. Its nearest populations are found further northwest at the Papigochi-Tutuaca basin $(2,073 \mathrm{~m}, 115 \mathrm{~km}$ to the NW straight distance), both tributaries of Río Bavispe-Yaqui, which flows to the west/southwest through the State of Sonora and reaches the Gulf of California. West of the Río Conchos basin and across the Sierra Madre ridges is the Río Mayo basin, whose main tributaries are the Río Candameña, Río Basaseachi and Río El Durazno, which merge to form the Río Mayo, that flows to the Gulf of California. A similar situation is that of the Río Fuerte basin, which includes many tributaries such as Río Batopilas, Río Verde and Río Urique, which flow through Barrancas del Cobre (Cooper Canyon), then merge to form Río Fuerte and drain into the Gulf of California. Although, the recently released otters mentioned above (Long 2010) are not likely to have given rise to the otter population that we are reporting here, because of the long distance that separates the site of reintroduction from the area where the population we are describing inhabits and that Carrillo-Rubio and Lafón (2004) were studying before 2004. Further south of the Río Conchos basin is the Río Nazas basin (in the State of Durango), an endorheic basin that is heavily used for irrigation. It is known that its headwaters were once inhabited 
by otters regarded as Neotropical otters by Pohle (1920) and Gallo-Reynoso (1997), but their settings is similar to those of the Río Conchos and therefore should be occupied by L. canadensis.

The undetermined taxonomic identity of otters of the Río San Pedro, in the Conchos basin by Carrillo-Rubio and Lafón (2004) and the recent depiction as belonging to the Nearctic otter by Ceballos and Carrillo-Rubio (2017), based solely on camera - trap photographs of the rhinarium shape of the species, not in hard evidence, as it is to review a specimen. This situation raises questions on their conservation status along the basin, which in their middle portion has been subject to strong anthropogenic pressure over its probable historical range, particularly in aquatic habitats. Adding to this, an unconfirmed sighting of a river otter reported by Carrillo-Rubio (2002) in the lower Conchos. Later, supported with photographs of an area used by otters in 2009 and with an otter trail in 2010 (Jaen, pers. comm. to J. P. Gallo-Reynoso) in the Pegüis Canyon, near the confluence of Río Conchos with Río Grande, within an area proposed for conservation. The taxonomic status of these specimens remains unknown, although they might be Nearctic otters.

Nearctic otters currently lack protection from the Mexican authorities, since the two subspecies previously reported in Mexico, i. e., Lontra canadensis sonora from the Colorado River and Lontra canadensis lataxina from the Río Grande, are regarded as extinct in México (Gallo-Reynoso and Casariego 2005). They are not listed under any protection category by wildlife authorities of México (NOM-059ECOL-2010).

Neotropical otters are regard as 'threatened', their main threat is habitat fragmentation and pollution (Gallo-Reynoso 1989, 1997), which restricts gene flow among populations, thus increasing their risk of extinction (Hedrick 1985; Frankham et al. 2002). Habitat fragmentation is most likely the cause for the distribution of Nearctic otters, restricted to the tributaries of the upper Río Conchos in a relict environment. Downstream, river otters are expose to seasonal dry conditions throughout the Chihuahuan desert when runoff is minimum in spring (Hudson et al. 2005). Anthropogenic activities play a role as well, including water diversion with reservoirs and channels for large agricultural areas, urbanization, and removal of riparian vegetation by cattle, and water pollution by large cities and industry (Ramos-Rosas et al. 2012). In Mexico, all these activities are common for agricultural purposes, while water demand to fulfil the growing population needs has led to extensive construction of dams throughout the country (Sánchez and Gallo-Reynoso 2007). Moreover, the upper Río Conchos probably represents the southernmost limit of the distribution range of the Nearctic otter, which could further compromise the genetic connectivity between otter populations, given that the habitat in this area tends to be more fragmented and of marginal quality (Gaston 2009; Sexton et al. 2009).
Further studies will contribute to identify habitat features associated with species occupation, as well as geographic or climatic barriers that restrain gene flow across basins. These will provide valuable information to assess habitat connectivity, a central issue when establishing corridors to ensure the long-term conservation of the species (Pearse and Crandall 2004; Cushman et al. 2006; Latch et al. 2008). Research on the association between river otters and the habitats in which they live is key, since otters are closely associated with their habitat, and therefore are considered bio-indicators of ecosystem health (Kruuk 2006; Waldemarin and Alvares 2008; Guerrero et al. 2015; Rheingantz and Trinca 2015).

In the present study, we used habitat and population approaches aimed at 1 ) identifying the species that inhabits the Río Conchos basin; 2) assessing the status and population structure of the species inhabiting the San Pedro, Conchos and Santa Isabel rivers; 3 ) proposing conservation measures for this species and its habitat based on our findings.

\section{Methods}

Study Area and Sampling. The Río San Pedro (1,467 m) was survey in November 2015, by walking along riverbanks to record the presence of otters (tracks, spraints, dens, food remains) in the middle and lower portions of the basin. We observed an adult individual at a small creek that flows into Río San Pedro. We collected 14 spraints and set-up four camera traps (Bushnell HD 12 megapixels, with an SD card of 32 gigabytes) facing their latrines. In December 2015 we retrieved the cameras from Río San Pedro and explored Río Conchos near Nonoava, $40 \mathrm{~km}$ to the southwest, above the Francisco I. Madero reservoir and the confluence of the San Pedro and Conchos rivers. There we obtained spraints and observed several otter tracks along $5 \mathrm{~km}$ of the stream. In addition, the tanned fur of a juvenile otter was given to us and is now in the reference collection of vertebrates at Laboratorio de Ecofisiología, CIAD-Guaymas. In June 2017, we surveyed the middle portion of Río Santa Isabel and found tracks, spraints, food remains and latrines of river otters. No live wild animals were handled in the present study.

The total area monitored spanned along $20 \mathrm{~km}$ of river, divided into three portions: two areas in Río San Pedro, each measuring $5 \mathrm{~km}$ in length, and separated by a section of $10 \mathrm{~km}$. In both areas of Río San Pedro, we recorded habitat features that are key for otters, such as vegetation cover, presence of pools, fish availability, and rocky areas used for latrines where otter spraints are dump. The third area was located at Río Conchos, and the fourth area was located at Río Santa Isabel, in these two rivers, $5 \mathrm{~km}$ of riverbanks were surveyed.

As control, we survey Arroyo Bamochi $(1,187 \mathrm{~m})$ in the Bavispe-Yaqui basin, State of Sonora, an area known to be occupied by Neotropical otters (Gallo-Reynoso et al. 2016); the same methodology was used to obtain otter records.

Hair examination. Primary $(\mathrm{PH})$ and secondary $(\mathrm{SH})$ hairs from the fur of the juvenile specimen were compared fol- 
lowing the methodology of Kuhn and Meyer (2010), with similar hairs from two furs of adult Lontra longicaudis (from Río Bavispe in Sonora, and from San Miguel Pochutla, Oaxaca; both furs are deposited in the reference collection of vertebrates at Laboratorio de Ecofisiología, CIAD-Guaymas). PH were obtained from a $1-\mathrm{cm}^{2}$ fur section, cut from the right flank; hair length was measured to differentiate $\mathrm{PH}$ and $\mathrm{SH}$ from the three individuals. All hair samples were observed under an Olympus BX41 XploRA Raman technology microscope at 10X and 40X to differentiate hair medulla and scales of the three specimens.

Habitat. To evaluate the interaction between individuals, and habitat characteristics in the study area, we used a Garmin GPS (GPSmap 78s) to generate the track of the areas surveyed; tracks were upload as a Kml files in Google Earth to produce maps of the distance of the otter habitat surveys, as well as the river elevation profile (slope). The aim was to map the distribution of otters in the upper Río Conchos-San Pedro basin, and Río Bavispe-Yaqui basin, based on geographical features such as elevation and tributary network, since such habitat characteristics are known to affect abundance, dispersal and/or occupancy by otters. Data on river basins were obtained from Comisión Nacional para el Conocimiento y Uso de la Biodiversidad (Mexico's National Commission for the Knowledge and Use of Biodiversity, CONABIO).

Camera trap survey and otter behavior. Camera traps

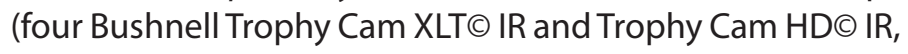
all of 5-8 megapixels with a SD card of 32 gigabytes) were set up to record photographs and videos. Video length was $20 \mathrm{~s}$ in all cases, with a separation of 1 min between capture events. In cameras taking still photographs, three photos were taken per event, separated by 1 min between events. Total effort accounted for 100 trap-days. These photographs and videos were used to estimate the otter population structure. By identification of different otter age/sex categories using the latrines (observing their marking behavior and genitalia, we were able to identify males, subadult male, adult female, juvenile, lone individuals of either sex, mother-offspring groups and unidentified individuals), and frequency (number of days) and time (hours) of latrine use in the area. Cameras also collected data on ambient temperature, moon phase and other habitat characteristics, such as changes in flow, all of which might influence the presence of otters at latrines/camera -trap sites (Table 1). Cameras also recorded environmental sounds and vocalizations, such as barks, whistles, grunts, etc., from otters and other species in the area, including birds. Camera traps were tied to tree trunks, positioned near or over otter latrines at 2.5 to $4 \mathrm{~m}$ high to avoid flash floods.

We deployed four similar camera traps at Arroyo Bamochi in the Río Bavispe-Yaqui basin (Sonora), with the same methodology to record photographs and videos of Neotropical otters, to ascertain the identity and differences of the two otter populations. In both rivers, cameras positioned at $1.25 \mathrm{~km}$ from each other, covering an area of 5 $\mathrm{km}$. Left for a month to record photographs and videos.
Table 1. Location of camera-traps used to record the presence of Nearctic (Río San Pedro, November - December 2015) and Neotropical (Arroyo Bamochi September October 2015) otters. All cameras were placed on tree trunks at 2.5 to $4 \mathrm{~m}$ height.

\begin{tabular}{lrrrr}
\hline & \multicolumn{2}{c}{ Río San Pedro } & \multicolumn{2}{c}{ Arroyo Bamochi } \\
Camera & Latitude & Longitude & Latitude & \multicolumn{1}{c}{ Longitude } \\
\hline 1 & 27.86036 & -106.34138 & 30.14022 & -109.03294 \\
2 & 27.86139 & -106.34341 & 30.14211 & -109.03019 \\
3 & 27.86269 & -106.34850 & 30.14386 & -109.03038 \\
4 & 27.86292 & -106.34841 & 30.14536 & -109.03202 \\
\hline
\end{tabular}

Relative abundance was estimated by dividing the number of otters recorded by the area covered by all cameras ( 5 $\mathrm{km})$, to assess the total number of individuals $/ \mathrm{km}$.

Relationship between ambient and water temperature was obtained with the frequency of otter records at different times of the day, and the ambient temperature recorded by the camera. Water temperature were obtained by measuring it on the spot at different hours during day light and with records from the nearest agricultural measuring station.

Prey availability. Fish were filmed underwater in large and deep pools in both locations with a GoPro Hero2@ camera to estimate prey availability. The camera tied to a $1.5 \mathrm{~m}$ pole and moved slowly sideways in a vertical position while filming. Several fish species were filmed and posteriorly identified, at least four large key species in each river, all being present in otter spraints collected in both localities. A Río San Pedro's large pool was measured, length, wide and depth ( $10 \mathrm{~m}$ wide by $30 \mathrm{~m}$ long, by $2.5 \mathrm{~m}$ deep), containing approximately $96,250 \mathrm{~m}^{3}$. The pool at Arroyo Bamochi ( $7 \mathrm{~m}$ wide by $25 \mathrm{~m}$ long, by $1.70 \mathrm{~m}$ deep), equivalent to $65,391 \mathrm{~m}^{3}$. Fish length and weight were also measured from fishes captured in the localities and compared to the mean sizes of the species reported in the literature, or in FishBase (www.fishbase.org); from these, an estimated mass $(\mathrm{kg})$ of prey available for otters were obtained for each pool. Identification of fish prey were done following Page and Burr (1991), Lima et al. (2003), Trewavas (1982) and De La Maza-Benignos (2009).

\section{Results}

Otter specimen collected. In 2013, we were informed of a juvenile otter from Río San Pedro that was injured by peasants near its den, taken alive and kept in captivity at the municipality of Belisario Dominguez (Chihuahua), this otter later died in captivity. The local authorities contacted us (Nuñez, V., and J. P. Gallo-Reynoso) and sent photographs of the otter for identification; the specimen possessed characteristics that were clearly different from Lontra longicaudis. Based on cephalic traits (lateral view), the specimen otter profile corresponds to the Nearctic otter: the head and nose are straighter than in the Neotropical otter, in which both structures are more concave (Figure 2). The upper lips were more inbound to the mouth than in Neotropical otters, a characteristic of Nearctic otters. The coloration of the individual was paler than in L. longicaudis. In Decem- 


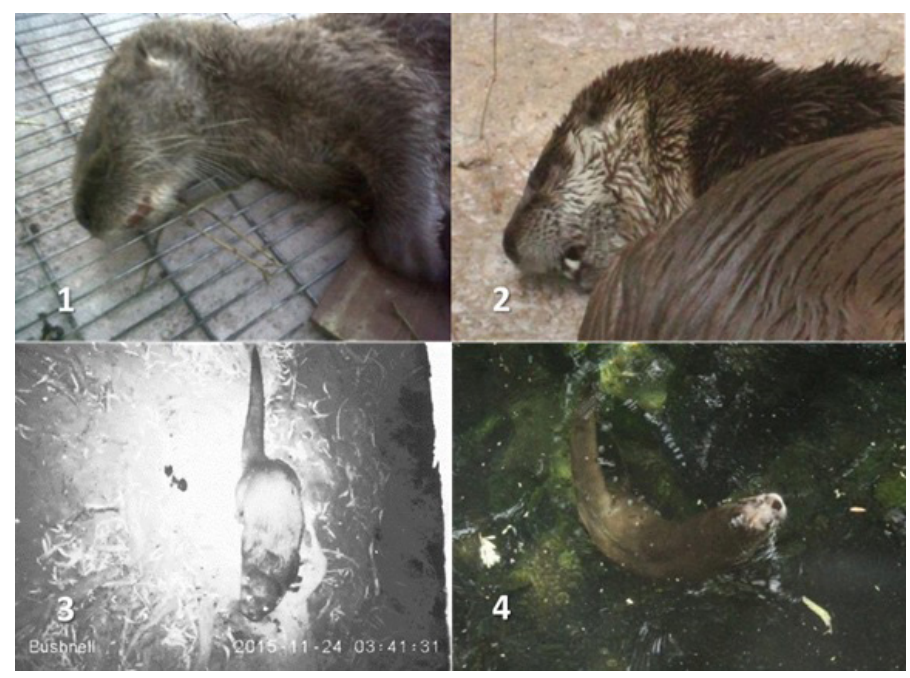

Figure 2. Comparative morphology and specific rhinarium form of Nearctic otters from Río San Pedro, Chihuahua, México, with a captive Nearctic otter at The Arizona Sonora Desert Museum (Tucson AZ). 1) Lateral view and coloration of the juvenile from Río San Pedro (V. Nuñez 2013). 2) Lateral view and coloration of an adult Nearctic otter (scratching its head sideways) at the Arizona Sonora Desert Museum (I. Barba-Acuña 2016). 3) Rhinarium of the Río San Pedro otter (J. P. Gallo-Reynoso, Bushnell Trophy Cam December. 2015). 4) Rhinarium of a Nearctic otter at the Arizona Sonora Desert Museum (I. Barba-Acuña. 2016).

ber 2015, the fur of that juvenile was donated to us; at a first glance, the rhinarium resembled that of a Neotropical otter, but at close examination, and removing the stiffness of the nose (due to the drying and subsequent tanning process), corresponded to Lontra canadensis. To the touch, the fur was fluffier than in Neotropical otters. The soles of the individual had hairs between the pads, which is present in Nearctic otters, and a feature absent in Neotropical otters, whose sole is completely bare of hair.

Hair differences. Guard hairs or PH on the flank and dorsum of the juvenile otter were 20 to $24 \mathrm{~mm}$ long, and the underfur or SH were 12 to $18 \mathrm{~mm}$ long. According to Kuhn and Meyer (2010), in L. canadensis mean PH length is $24 \pm$ $0.9 \mathrm{~mm}$ (individual variation from 17 to $29 \mathrm{~mm}$ ), and mean SH length is $15 \pm 1.3$ (individual variation from 12 to $20 \mathrm{~mm}$ ).

While the two L. longicaudis furs examined had a $\mathrm{PH}$ length of 15 and $16 \mathrm{~mm}$, which SH measured 5 and $7 \mathrm{~mm}$ showing some variation between localities being shorter in the more tropical settings (fur from Oaxaca) than in the northern one (fur from Sonora). According to Kuhn and Meyer (2010), in L. longicaudis mean PH length is $16 \pm 1.5$ $\mathrm{mm}$ (individual variation from 12 to $22 \mathrm{~mm}$ ) and mean $\mathrm{SH}$ length is $8 \pm 0.6$ (individual variation from 5 to $10 \mathrm{~mm}$ ); therefore, based in the above fur differences, the juvenile otter fur from Río San Pedro corresponds to L. canadensis.

Primary hairs from the juvenile, observed under microscope at 40X are similar to Nearctic otter PHs as described at pars intermedia, hair cuticle scales are "narrow diamond petal", differing from Neotropical otter pars intermedia hair cuticle scales that are "diamond petal" (Figure 3).

We observed an adult individual downstream of the Arbolito creek dam, which is a tributary to San Pedro. Its body movement was consistent with a Nearctic otter, later observed in videos of several individuals. Images obtained

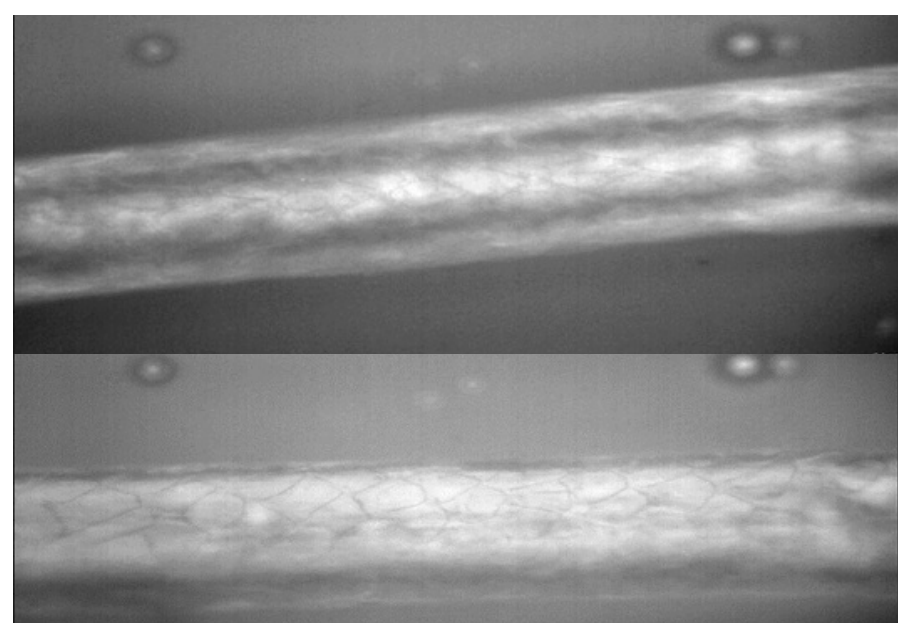

Figure 3. Pars intermedia primary hair scales of Nearctic and Neotropical otters as shown under 40X Raman Microscope. Shape of cuticle scales of L. canadensis described as "narrow diamond petal" (upper photograph), compared to the shape of cuticle scales of L. longicaudis as "diamond petal" (lower photograph) sensu Kuhn and Meyer (2010). Hairs of the Nearctic otter are thicker than hairs of the Neotropical otter.

from the videos show different individuals with the typical rhinarium of Nearctic otters; however, the quality of videos is not sufficiently clear to make an in-depth differentiation; in addition, individuals do not always face the camera. The body shape of adult males filmed is sturdier (rounded and shorter) relative to Neotropical otters, which are longer and slender. Adult individuals from Río San Pedro were compared to an adult individual of $L$. canadensis filmed by us at the Arizona Sonora Desert Museum, Tucson, Arizona (April 2016); their movements, overall body shape, fur color, tail length and broad base of tail are all similar (Figures 2 and 6).

Tracks of the individuals studied at Río San Pedro are similar to tracks of the Nearctic otter and are different from those of L. longicaudis. The posterior paws of the Nearctic otter typically steps on the print of the forepaw, producing distinctive tracks that made possible to differentiate between both species. In Neotropical otters, the posterior paw rarely steps on the print of the forepaw when this happens, the posterior feet step sideways of the forepaw print, sometimes stepping over a little, usually by the external side.

Habitat. The sites surveyed at Río San Pedro, Río Santa Isabel and a portion of the Río Conchos comprised a total linear distance of $20 \mathrm{~km}$ of continuous otter habitat, including deep pools, rapids, meanders, shallow areas, boulders, and rocky cliffs. Riverbank areas showed a low diversity of trees (Salix sp., Prosopis sp., Populus sp., Quercus spp., Juniperus sp., Fraxinus sp.), while the herb stratum was dominated by batemote or seep willow (Baccharis salicifolia) and grass (Bouteloua sp.). Otters preferred areas protected by willows than other trees at Río San Pedro, Conchos and Santa Isabel.

The site monitored at Arroyo Bamochi also comprised a linear distance of $20 \mathrm{~km}$ of continuous otter habitat, including deep pools, shallow areas, two freshwater springs, boulders and rocky cliffs. Riverbanks were covered with a large diversity of trees (Acer grandidentatum, Alnus oblongifolia, Fraxinus velutina, Junglans mayor, Salix goddingii, Prosopis sp., Populus fremonti, Populus brandegeei, Platanus wrightii, 
Juniperus deppeana and Quercus spp.), and the herb stratum was composed by batemote or seep willow (B. salicifolia), jecota (Hymenocclea monogyra), cardo (Argemone mexicana), sedge (Carex sp.), and others. Due to extended protection by trees, otters did not show preference of areas covered by a particular species of tree.

Camera traps. The total effort was 100 trap-days (no photographs, 2,150 videos) at Río San Pedro, and 136 trap-days (983 photographs, 82 videos) at Arroyo Bamochi, Sonora. We obtained a total of 86 high-quality otter individual identifications at Río San Pedro and 30 at Arroyo Bamochi, 116 positive individual identifications (0.49 identifications/day). The total number of otters with positive individual identifications in the area covered by cameras were nine at Río San Pedro (two large males, two adult females, one juvenile female, one juvenile male, one undetermined-sex juvenile, a large cub and an unidentified individual). There were 11 individuals identified at Arroyo Bamochi (two large males, a female with a large cub, a female with two smaller cubs, a solitaire female, two juvenile males and an unidentified individual). There is no signficative difference (t-test, $\mathrm{t}=1.309307, d$. $f .=9$, $P=0.265384, n=10$ ) in the number of otters in the two similar area sites. The relative abundance of otters was 1.8 otters $/ \mathrm{km}$ at San Pedro and 2.2 otters $/ \mathrm{km}$ at Bamochi. The difference in relative abundance between the two streams is not significant, despite the differences observed in the local habitat, evidenced by the abundance and diversity of riparian vegetation as described above. An important difference between these two watercourses is the amount of pools in the habitat and the available running water, being larger at Río San Pedro than at Arroyo Bamochi.

Associations between trees, secondary vegetation, rocky cliffs and access to large pools where the most common sites where the two otter populations have their dens and/or latrines. Otter Behavior. Camera-trap videos were useful to compare the behaviour regarding visits to latrines, vocalizations and general movements of otters while sniffing spraints, dropping and urine marking of latrines. Data on moon phase, ambient temperature and hour of the day serve to evaluate the response of otters to these environmental features. Nearctic otters were more visible during daylight hours than Neotropical otters, which preferred crepuscular and night hours. Relationship with water temperature. Río San Pedro is at 1,467 m, while Arroyo Bamochi at 1,187 m, a differential altitude of $280 \mathrm{~m}$. Despite of this, it is notorious that ambient and water temperature behaves very different in each river. The ambient temperature is $8^{\circ} \mathrm{C}$ higher at Arroyo Bamochi (range: 16.8 to 24.7), than at Río San Pedro (range: 3 to 19 ${ }^{\circ} \mathrm{C}$ ), water temperature behaves similar, with $8{ }^{\circ} \mathrm{C}$ higher at Arroyo Bamochi (range: 9.1 to $20.3^{\circ} \mathrm{C}$ ) than at Río San Pedro (range: 8.8 to $13.3^{\circ} \mathrm{C}$ ). These differences in temperature might explain why the frequency of visitation of camera - traps - latrine combination is different in both species. Otters at Río San Pedro are visible in the river at almost any hour of the day, avoiding only the warmest hours, while Neotropical otters, preferred to be crepuscular and in the night than in the middle of the day, which is probably very hot for them. This correlates with the type of $\mathrm{PH}$ and $\mathrm{SH}$ hair, and its size, being longer where the water is significantly colder, and smaller where water is warm. Therefore, temperatures (of water and ambient) might also be an important barrier for the distribution of both species (Figures 4A and 4B).

Prey Availability. Fish species observed in the pool at Río San Pedro, near camera traps were: Largemouth bass (Micropterus salmoides), 25 ind. ( $30 \mathrm{~cm}$ mean length and $\sim 2 \mathrm{~kg}$ mean weight $=50 \mathrm{~kg}$ ). Río Conchos matalote (Catostomus bernardini), 52 ind. ( $40 \mathrm{~cm}$ mean length and $\sim 2 \mathrm{~kg}$ mean weight $=104 \mathrm{~kg}$ ). Sardinita (Astyanax mexicanus), 25 ind. ( $10 \mathrm{~cm}$ mean length and $\sim 75 \mathrm{~g}$ mean weight $=1.9 \mathrm{~kg})$. Introduced tilapia (Oreochromis mossambicus), 36 ind. ( 18 mean length $\mathrm{cm}$ and $\sim 1 \mathrm{~kg}$ mean weight $=36 \mathrm{~kg}$ ), as well as smaller unidentified fish. Fish availability in this pool as otter prey was estimated at $192 \mathrm{~kg}$.

Fish species observed at the pool of Arroyo Bamochi, near camera traps were: Largemouth bass (M. salmoides); 13 ind. ( $\sim 30 \mathrm{~cm}$ mean length and $\sim 2 \mathrm{~kg}$ mean weight $=26$ $\mathrm{kg}$ ). Río Yaqui matalote (Catostomus yaqui), 30 ind. $(\sim 40 \mathrm{~cm}$ mean length and $\sim 2 \mathrm{~kg}$ mean weight $=60 \mathrm{~kg})$. Introduced tilapia (O. mossambicus), 26 ind. ( $18 \mathrm{~cm}$ mean length and $\sim 1 \mathrm{~kg}$ mean weight $=26 \mathrm{~kg}$ ), and smaller unidentified fish. Total fish estimated availability in the pool was $112 \mathrm{~kg}$.
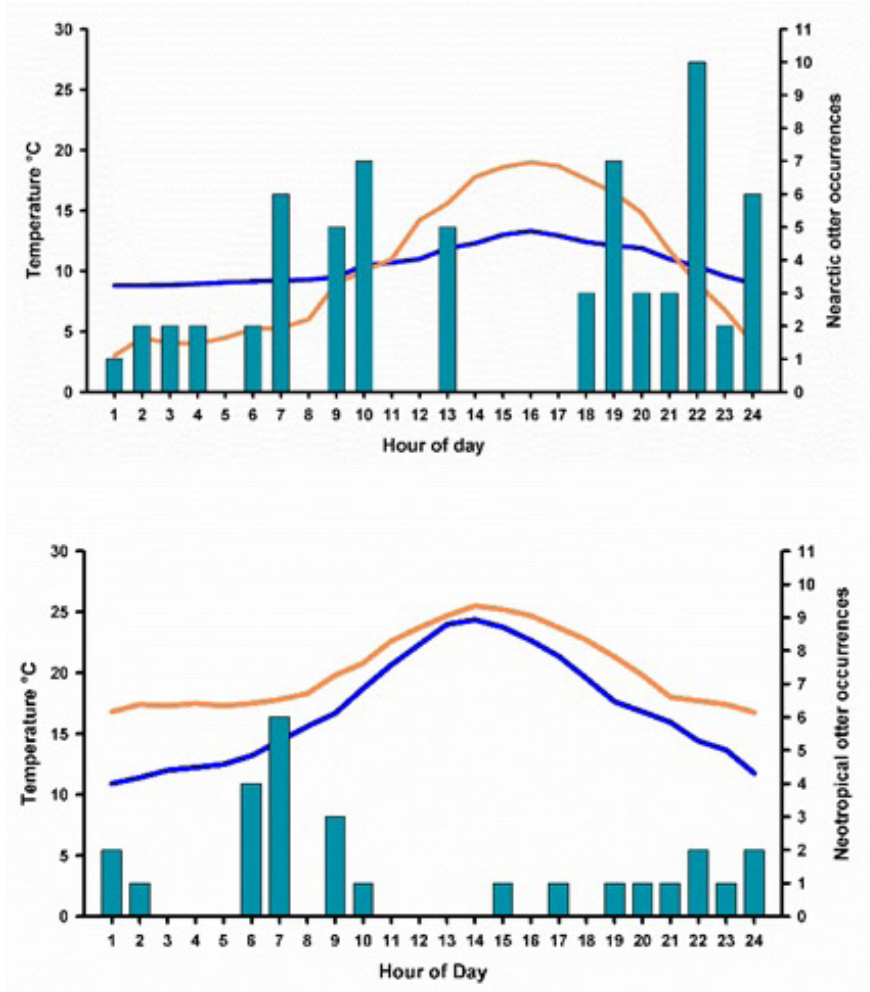

Figure 4. A and 4 B. Differences in observation of Nearctic and Neotropical otters related to ambient and water temperature. Blue line represents water temperature. Orange line represents ambient temperature. Bars are the number of occurrences of otters in one latrine over a 30-day period. 


\section{Discussion}

Otter species Determination. The different sources of evidence, such as habitat connectivity, photographic confirmation of external morphology and rhinarium shape, as well as hair and fur characteristics of the specimens examined, led us to conclude, that the otter species inhabiting the Río San Pedro, Río Conchos and Río Santa Isabel basins in Central Chihuahua, is Lontra canadensis, the Nearctic otter, representing a relict population that has survived the isolation from otters inhabiting Río Grande (Figures 3 and 4). It is notable that the hair coloration and thickness are also different in the specimens analysed, being tan-coloured in the juvenile $L$. canadensis and copper-coloured in the two adult $L$. longicaudis, thicker in L. canadensis and slender in $L$. longicaudis. Based on these traits, the fur of the juvenile otter from Río San Pedro correspond to the Nearctic otter.

Additional morphological features when comparing the juvenile specimen vs. individuals of $L$. longicaudis of similar size (Gallo-Reynoso et al. 2013) are the following. The tail of the juvenile specimen measures $37 \mathrm{~cm}$, which is shorter than in similar sized specimen of $L$. longicaudis, which measures $42.7 \mathrm{~cm}$. However, the base of the tail is broader in the juvenile specimen than in L. longicaudis. In general, the fur is paler in the dorsum (brown-ash), which contrasts with the dark brown color of the two L. longicaudis specimens examined.

If the species inhabiting the San Pedro, Santa Isabel and Conchos rivers belonged to the Neotropical otter, there should exist an extensive habitat connectivity along a conspicuous corridor, where the gene flow of the Neotropical otter would have been able to cross the eastern slopes of the Sierra Madre towards the Central Plateau, and across the Chihuahuan Desert.

If such connection ever existed after the past glaciation period, the most likely corridor was the Río Papigochi-Tutuaca to the northwest where we have records of the Neotropical otter $(2,079 \mathrm{~m})$, which is the closer one to the Río San Pedro basin at higher elevations. The Río PapigochiTutuaca basin serves as a corridor that connects habitats from Chihuahua down to the west reaching as far as Sonora; it is a high-altitude oak-pine grassland habitat, which turns into a desert scrub habitat in Sonora (Gallo-Reynoso et al. 2016). The Río San Pedro $(1,467 \mathrm{~m})$ is located to the southeast, $116 \mathrm{~km}$ away (straight line) from Río Papigochi-Tutuaca. Río Santa Isabel $(1,548 \mathrm{~m})$ to the east at $109 \mathrm{~km}$ away (straight line) from Río Papigochi-Tutuaca. A large mountain range of 2,350 $\mathrm{m}$ separates these basins and the elevation differential is of $569 \mathrm{~m}$; therefore, we can conclude that there is no habitat connectivity. To the south, Río San Pedro and Río Conchos headwaters are located at around 2,100 $\mathrm{m}, 400 \mathrm{~m}$ lower than the more than 2,700 m peaks of the Sierra Madre ridges that divide the Río Conchos basin from the Río Mayo and Río Fuerte basins to the west, inhabited by Neotropical otters. There is a null habitat connectivity of the Conchos basin with Río Bavispe (Papigochi-Tutuaca),
Río Mayo and Río Fuerte basins.

In terms of the effect of habitat connectivity on the distribution of otters, elevation and slope are the most important geographic characteristics that separates the two species, implying a reduction in gene flow as elevation and slope increases (Guerrero et al. 2015). These results agree with previous findings by Guerrero et al. (2015) who used a landscape-genetic approach to examine how the ridges that delineate basins affect the gene flow, and therefore the distribution, of Neotropical otters in Mexico. These authors found a positive correlation between the genetic distance of individuals in different basins and the mean slope separating the basins, showing that steep elevations and dry land restrain otter dispersal. In other studies of habitat suitability, slope and elevation were found to affect otter dispersal (Loy et al. 2009; Carranza et al. 2011).

In otter species, habitat connectivity is usually assessed by differentiating between longitudinal and lateral connectivity. Longitudinal connectivity refers to the ability of otters to move within a river basin; lateral connectivity, to dispersal movements across basins, resulting in gene flow among populations inhabiting adjacent basins (Gallo-Reynoso 1989; Carranza et al. 2011; Van Looy et al. 2014; Guerrero et al. 2015). Natural boundaries among watersheds, such as ridges, could restrain lateral connectivity; this seems to be the case for this otter population, as high elevations and steep slopes were found to restrict the distribution of Neotropical otters as shown by Guerrero et al. (2015).

Conservation Implications. It is general knowledge that well-connected waterways and low levels of human disturbance are key for the occurrence and survival of Neotropical and Eurasian otters (Gallo-Reynoso 1997; Kruuk 2006; Santiago-Plata 2013); accordingly, we assumed that urban and agricultural land would have a detrimental effect on habitat connectivity for Nearctic otters. However, Eurasian and Neotropical otters tolerate heavy human disturbance, as long as there is sufficient prey availability (Gallo-Reynoso 1997; Lariviere 1999; Kruuk 2006; Sales-Luís et al. 2009; Reid et al. 2013). In this study, we incorporated prey availability as a predictor of habitat stability and use. In studies addressing habitat suitability for both Eurasian and Neotropical otters, riparian vegetation density and riverbank slope have shown to be key drivers for otter habitat connectivity (Jeffress et al. 2011; Pardini and Trajano 1999; Loy et al. 2009; Santiago-Plata 2013).

Our results show areas with favourable habitat characteristics and large prey availability at lower Río San Pedro, middle Río Santa Isabel and upper Río Conchos, and point to the existence of three potential areas that are suitable for the distribution of the Nearctic otters. However, sampling efforts should increase to unveil additional areas where favourable conditions in terms of habitat connectivity and prey availability are found. Although topographic features (i. e., steep slopes and high elevations) may serve as natural limits between watersheds in the Río Conchos basin, in 
this study these were not found to restrain otter distribution within the basin. In this regard, a good starting point for identifying management units would be to select basins as sampling units and use non-invasive methods, such as latrine sites coupled with camera traps, to continue the longterm monitoring and characterization of otter populations.

In addition, anthropogenic disturbances affecting riverbed configuration could further hinder connectivity. In this regard, it has been proposed that damming could disrupt the connectivity of otter populations by imposing barriers to dispersal (Mason 1995; Gallo-Reynoso 1997; Pedroso and Santos-Reis 2009). Consequently, we propose that conservation corridors for the Nearctic otter be establish in the Upper Río Conchos basin, where adjacent tributaries are delimited by low elevations and slopes, therefore, conservation corridors interconnecting these three tributaries (San Pedro, Santa Isabel and Conchos) upstream of the dams should be established to guarantee habitat connectivity and longitudinal gene flow. There should not be built new infrastructure such as dams and open mines within their riparian zone that might have significant impacts on otter populations. The latter could prove especially challenging, as three high-capacity dams (i. e., higher than $50 \mathrm{~m}$ ) were built some time ago along the Conchos' basin. Río Satevó and Río Santa Isabel converge before joining the Río San Pedro, their waters are trapped by the Francisco I. Madero dam. South from this, the Boquillas Dam encloses the Río Conchos waters, downriver the Conchos flow joins the Río Florido and they now flow to the confluence with the Río San Pedro (downriver of the Francisco I. Madero Dam), after this confluence, the Río Conchos is confined again by El Granero Dam. In all this area of the middle Conchos Basin, water is divert to irrigate important agricultural areas. There are no confirmed records (historical or recent) of otters in this area, and therefore there is no corridor across the middle to the lower Conchos Basin through which this otter population could maintain genetic connectivity with this major area of Río Grande basin in northern México and southern U.S. From the continental divide in the Sierra Madre Occidental eastern slope, down to the Gulf of Mexico.

The designation of conservation corridors for these otters will be a key factor (Frankham et al. 2002) to prevent the loss of genetic diversity, maintain the evolutionary potential, and protect their population. We consider that the upper Río Conchos basin could be a suitable conservation corridor, not only because it may facilitate gene flow across the different interconnecting tributaries (San Pedro and Santa Isabel tributaries), but also because of its potential role to connect the otter populations inhabiting Río Grande and the Gulf of México. Also, because these Nearctic otters have probably been distributed throughout the Sierra Madre eastern slope in the Río Conchos basin at least since the last glaciation (20 to $12 \mathrm{kya}$ ).

A major potential corridor can be delimited (Figure 5) along the Río Grande basin at the Mexico-U.S. border and the state limits between New Mexico and Texas. However, the terrain is largely mountainous due to the Sierra Madre Occidental that becomes the Rocky Mountains to the north; this corridor is restricted to a narrow strip of river running from southwestern Chihuahua to the Río Grande. Nevertheless, it is likely key for maintaining the connectivity between the Rocky Mountains and the Sierra Madre Occidental, and, is the only connection with otter populations that inhabit the Río Conchos basin. Although there are no studies on potential corridors for the Neotropical otter in Mexico, a contemporary study addressed the distribution of the jaguar (Panthera onca) in Mexico, and showed that the southern Pacific coastal plains function as a key corridor for this species (Rabinowitz and Zeller 2010). These authors stressed that the limited range of the jaguar is a major concern, and that the jaguar population in the area is affected by human activities. In the case of both species of river otters in Mexico, no study has identified corridors that should be preserved for their survival; the only reference are the proposals of Guerrero-Flores et al. (2015) and the one presented here.

The climate in northern México is drier, with extreme temperatures than in western, eastern and southern Mexico, which is mostly humid, subtropical and tropical. The otter populations studied here have prevailed in potentially most extreme and fragmented environments across the species range, which could further restrain the genetic connectivity with northern Nearctic otter populations; the last record of Nearctic otter in the Río Grande is that of Polechla et al. (2004). Even though, 23 Nearctic otters were reintroduced to the Río Grande basin in New Mexico (Long 2010), with an unknown outcome in terms of the future genetic composition. Nonetheless, within this area there is a potential corridor connecting the San Pedro, Santa Isabel and Conchos populations with populations living further to the east. The corridor follows the main course of

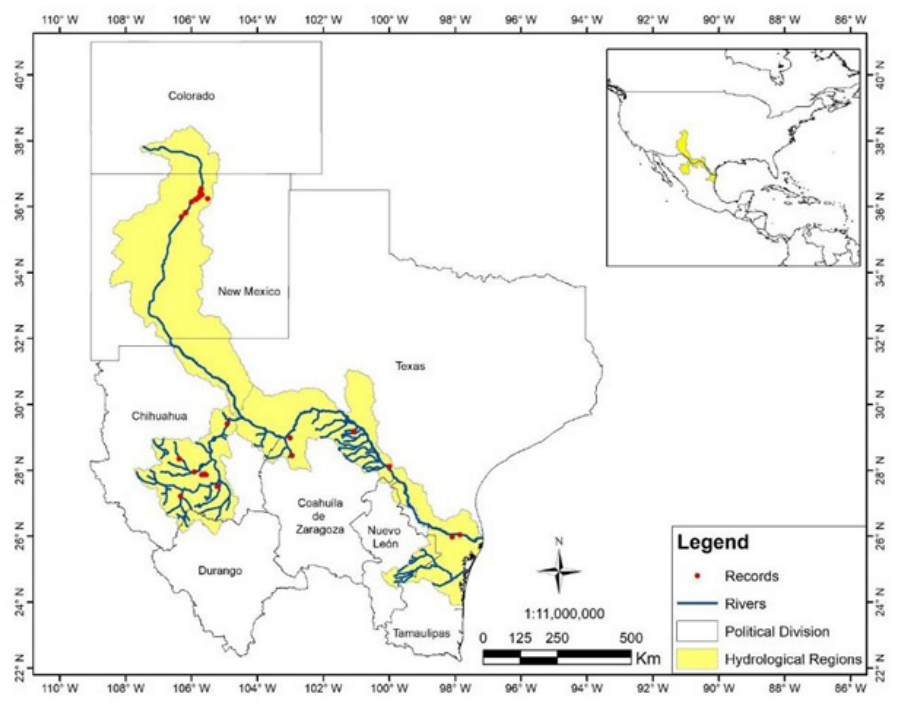

Figure 5. Distribution of the Nearctic otter at the Río Grande and Río Conchos basins in northwestern United States and northern Mexico. Red dots are our records of the species at Río San Pedro, Río Conchos and other records from Río Grande (GalloReynoso 1997; López-Vilchis 1998). Red dots in the upper basin of the Río Grande are recent sightings of reintroduced Nearctic otters (Long, 2010). The area in yellow is a corridor proposed for the conservation of Nearctic otters between Mexico and the U.S. 
the Río Grande, highlighting this as a key route to maintain the connectivity with Nearctic otters of New Mexico to the northwest, and of Texas to the east. However, the limited amount of surface water in the San Pedro, Santa Isabel and Conchos rivers, and the fact that natural watercourses are constantly altered to irrigate agricultural lands, used for cattle growing and with the presence of extensive mining operations in this region, are resulting in a long-lasting disruption to river ecosystems (Gallo-Reynoso 1997; GómezÁlvarez et al. 2011). There are other potential conservation corridors within the Nearctic otter range; the challenge will be to control the ever-growing anthropogenic impact within the Conchos basin.

Future directions in conservation. The International Union for Conservation of Nature (IUCN) classifies the Nearctic otter as 'least concern', with a stable population (Serfass et al. 2015). Nevertheless, as the relict population studied here is isolated, it must be considered as "Threatened" in México by the IUCN. It is imperative to conduct research on landscape genetics (Guerrero et al. 2015) to investigate the distribution range of the species, biogeographic barriers, habitat connectivity, otter populations, habitat relationship and impact by anthropogenic uses and barriers (such as dams)

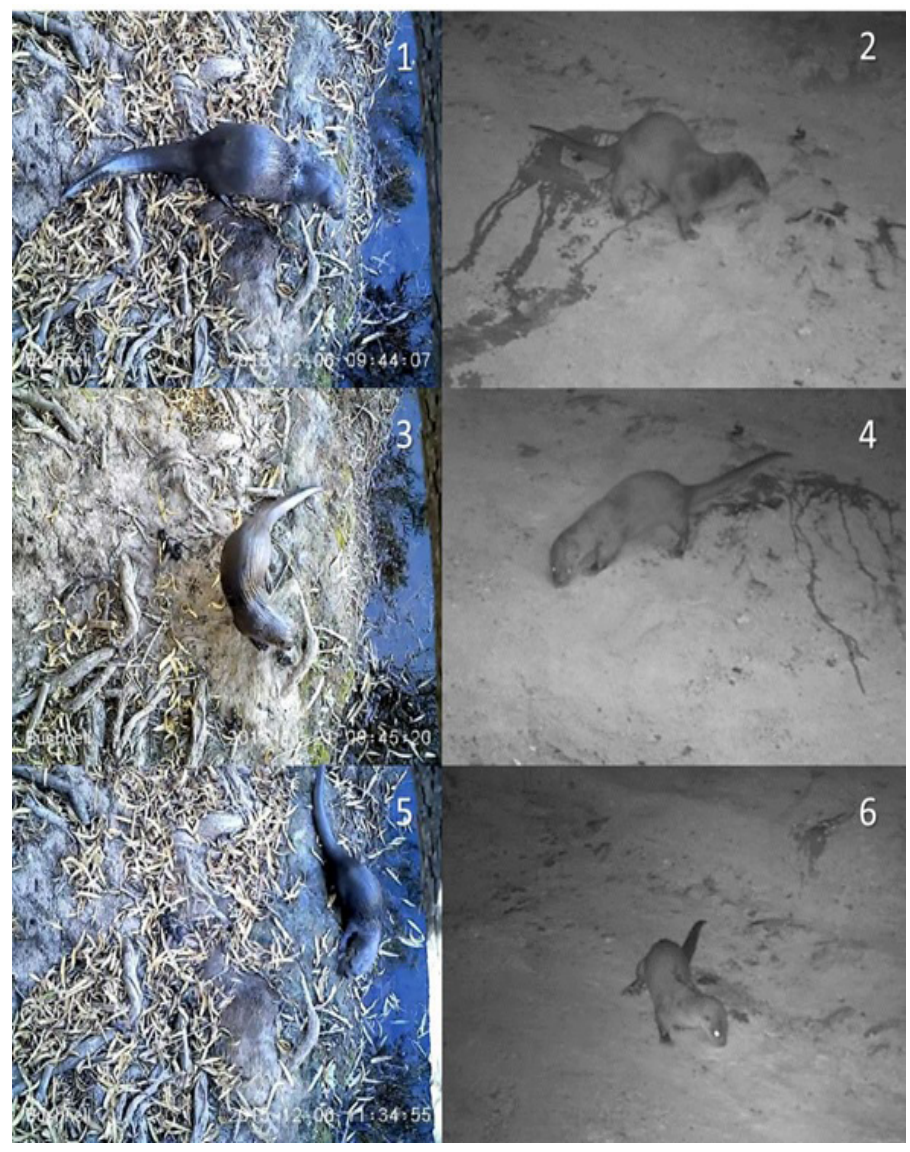

Figure 6. Comparative morphology between sexes of the same species and between both species of the Nearctic from Río San Pedro (Chihuahua, Conchos Basin), and Neotropical otters from Arroyo Bamochi (Sonora, Bavispe Basin). Nearctic otters are more active during daylight hours than Neotropical otters, which are active mainly at crepuscular and night hours. 1) Male of Nearctic otter. Río San Pedro, Chihuahua. 2) Male of Neotropical otter marking with urine. Arroyo Bamochi, Sonora. 3) Female of a Nearctic otter at Río San Pedro. 4) Female of Neotropical otter at Arroyo Bamochi, Sonora. 5) Juvenile of a Nearctic otter at Río San Pedro. 6) Juvenile of Neotropical otter at Arroyo Bamochi, Sonora. All photographs taken with Bushnell Trophy Cam. on gene flow. Therefore, allowing the identification of key areas for conservation in the upper Río Conchos basin, including the Río San Pedro and Río Santa Isabel where local populations, well preserved habitats with good relative abundance and large prey availability are now known (Carrillo-Rubio and Lafón 2004; Gallo-Reynoso et al. 2016; Ceballos and Carrillo-Rubio 2017). Based on our findings, we hereby propose to classify the population of Nearctic otters of the Río Conchos as an extant and relict population by the Mexican Wildlife and Conservation authorities due to its reduced and the strong human pressure throughout its downstream habitat.

Genetic analyses of the spraints collected are underway to confirm these findings. Immediate conservation measures are needed, and have been forwarded to the wildlife authorities in Mexico, Dirección General de Vida Silvestre (General Direction for Wildlife) and Comisión Nacional de Áreas Naturales Protegidas (National Commission of Protected Natural Areas), as the population described here is, to date, the only well-preserved population of this species reported in Mexico.

In terms of further avenues for research, there is a great need for obtaining updated information on the population size of this otter species in Mexico. There is virtually no information on this subject, as a single countrywide survey for the three otter species in México was conducted more than 20 years ago (Gallo-Reynoso 1997). Future studies could take advantage of capture-recapture analyses based on non-invasive genetic data, in order to gain an insight into population sizes (Marucco et al. 2010; Trinca et al. 2013). These efforts could be replicated spatially and temporally for the long-term monitoring of Nearctic otter populations in Mexico. Finally, there is a need to evaluate the role of this otter as an umbrella species for the lotic ecosystems and/ or as an indicator species of watershed conservation status.

\section{Acknowledgements}

This project was partly funded by PROCER 2015 of Comisión Nacional de Áreas Naturales Protegidas for Neotropical otter research in the Río Bavispe basin, as part of the larger Río Bavispe-Yaqui basin study in the states of Sonora and Chihuahua. Concurrent funds were allocated by CIADGuaymas for the Laboratorio de Ecofisiología. We thank J. R. Aragón-Guajardo from the Physics Department at Universidad de Sonora, who assisted with microscope images of otter hairs. We thank T. Serfass, M. Spinola and P. K. Koepfli, who assisted in the review of photographs for the correct identification of the species. This study was conducted under a permit issued by Dirección General de Vida Silvestre - SEMARNAT Oficio Núm.SGPA/DGVS/06582/15. María Elena Sánchez-Salazar edited the English manuscript.

\section{Literature cited}

Carranza, M. L., E. D’Alessandro, S. Saura, and A. Loy. 2011. Connectivity providers for semi-aquatic vertebrates: the case of the endangered otter in Italy. Landscape Ecology 27:281- 
290.

Carrillo-Rubio, E. 2002. Uso y modelación del hábitat de la nutria de río (Lontra longicaudis annectens) en el bajo Río San Pedro, Chihuahua. M. Sc. Thesis. Universidad Autónoma de Chihuahua. Chihuahua, México.

Carrillo-Rubio, E. And A. LAfÓn. 2004. Neotropical river otter micro-habitat preference in west-central Chihuahua, Mexico. IUCN Otter Specialists Group 21:10-15.

Ceballos, G. and E. Carrillo-Rubio. 2017. Redescubrimiento y estado de conservación de la nutria de río del norte (Lontra canadensis) en México. Revista Mexicana de Mastozoología Nueva época 7:1-12.

CONABIO (http://www.conabio.gob.mx/informacion/ metadata/gis/).

Cushman, S. A., K. S. McKelvey, J. Hayden, and M. K. Schwartz. 2006. Gene flow in complex landscapes: testing multiple hypotheses with causal modeling. American Naturalist 168:486-499.

De la Maza Benignos, M. 2009. Los Peces del Río Conchos. Alianza WWF - FGRA y Gobierno del Estado de Chihuahua. Chihuahua, México.

Findley, J. S., A. H. Harris, D. E. Wilson, and C. Jones. 1975. Mammals of New Mexico. University of New Mexico Press, Albuquerque, U.S.A.

Frankham, R., J. D. Ballou, and D. A. Briscoe. 2002. Introduction to conservation genetics Cambridge University Press. Cambridge, U.K.

Gallo-Reynoso, J. P. 1989. Distribución y estado actual de la nutria o perro de agua (Lutra longicaudis annectens Major, 1897) en la Sierra Madre del Sur, México. M. Sc. Thesis, Universidad Nacional Autónoma de México. Ciudad de México, México.

Gallo-Reynoso, J.P. 1997. Situación y Distribución de las nutrias en México, con énfasis en Lontra longicaudis annectens Major, 1897. Revista Mexicana de Mastozoología 2:10-32.

Gallo-Reynoso, J. P. and M. A. Casariego. 2005. Nutria de río, perro de agua. Pp. 374-376 in Los Mamíferos Silvestres de México (Ceballos G., and G. Oliva, eds.). Comisión Nacional para el Conocimiento y uso de la Biodiversidad, Fondo de Cultura Económica, Ciudad de México, México.

Gallo-Reynoso, J. P., S. Macías-Sánchez, E. Arellano-Nicolás, and A. GonzÁlez-Romero. 2013. Length, body mass, and growth of the Neotropical otter (Lontra longicaudis annectens) in Mexico. Therya 4:219-230.

Gallo-Reynoso, J. P., S. Macías-Sánchez, L. Armenta- Méndez, I. D. Barba-Acuña, V. A. Nuñez-Ramos, A. Loya Jaquez, G. Ponce-García, and A. Gardea-Béjar. 2016. Letrinas de nutrias y cámaras trampa ¿qué nos dicen? Otter latrines and camera traps, what do they tell us? In: Memorias XIII Congreso Nacional de Mastozoología. Asociación Mexicana de Mastozoología. Tuxtla Gutiérrez, Chiapas. Available at jpgallo@ciad.mx

GAston, K. J. 2009. Geographic range limits: achieving synthesis. Proceedings. Biological Sciences / The Royal Society 276:1395-406.

Gómez-Álvarez, A., J. L. Valenzuela-García, D., Meza-Figueroa, M., de la O-Villanueva, J. Ramírez-Hernández, J. Armendáriz-Tapia, and E. Pérez-Segura. 2011. Impact of mining activities on sediments in a semi-arid environment: San Pedro River, Sonora, Mexico. Applied Geochemistry 26:2101-2112.
Guerrero, J., J. P. Gallo-Reynoso, and R. Biek. 2015. Mitochondrial DNA diversity, genetic structure, and demographic history of the Neotropical Otter (Lontra longicaudis) in Mexico. Journal of Mammalogy 96:1162-1173.

HaLl, E. R. 1981. The mammals of North America. Wiley Interscience Publication. New York, U.S.A.

Hedrick, P. 1985. Genetics of Populations. Jones \& Bartlett Publishers. Portola Valley, U.S.A.

Housh, T. B., F. W. McDowell, And J. N. Connelly. 2003. Early and mid-Proterozoic crust of the Coahuila terrane preserved in xenoliths at Cascada de Basaseachic, southwestern Chihuahua. Geological Society of America. Abstracts with Programs 36:78.

Hudson, P. F., D. A. Hendrickson, A. C. Benke, A. Varela-Romero, R., Rodiles-Hernández, and W. Minckley. 2005. Rivers of Mexico. Pp. 1030-1084 in Rivers of North America (Benke A. and C. Cushing, eds). Elsevier. Amsterdam, Netherlands.

Jeffress, M. R., C. P. Paukert, J. B. Whittier, B. K. Sandercock, and P. S. GIPSON. 2011. Scale-dependent factors affecting North American river otter distribution in the Midwest. The American Midland Naturalist 166:177-193.

Jones, C. AND C. G. Schmitt. 1997. Mammal species of concern in New Mexico. Special publication: Life among the muses; papers in honor of James S. Findley. Museum of Southwestern Biology 3:179-205.

KRUUK, H. 2006. Otters: Ecology, Behaviour and Conservation. Oxford University Press, Oxford, U.K.

KunN, R. A. AND W. MeYer. 2010. Comparative hair structure in the Lutrinae (Carnivora: Mustelidae). Mammalia 74:291-303. LARIVIERE, S. 1999. Lontra longicaudis. Mammalian Species 609:1-5

Latch, E. K., D. G. Scognamillo, J. A. Fike, M. J. Chamberlain, and O. E. RHODES. 2008. Deciphering ecological barriers to North American river otter (Lontra canadensis) gene flow in the Louisiana landscape. The Journal of Heredity 99:265-274.

Lima, F. C. T., L. R. Malabarba, P. A. Buckup, J. F. Pezzi, R. P. da Silva, A. Vari, R. Harold, O. T. Benine, C. S. Oyakawa, N. A. Pavanelli, C. A. S. Menezes, M. C. S. L. Lucena, Z. M.S. Malabarba, R. E. Lucena, F. Reis, C. LANGeAnI, C., Moreira, et AL. 2003. Genera Incertae Sedis in Characidae. Pp. 106-168 in Checklist of the Freshwater Fishes of South and Central America (Reis, R. E., S. O. Kullander and C. J. Ferraris Jr., eds.). EDIPUCRS. Porto Alegre, Brasil.

LoNG, B. 2010. River otter monitoring in the Upper Rio Grande watershed in northern New Mexico, October 14, 2008 through January 21, 2010. New Mexico Department of Game and Fish.

LóPEZ-WILCHIS, R. 1998. Base de datos de mamíferos de México depositados en colecciones de Estados Unidos y Canadá. Universidad Autónoma Metropolitana. Unidad Iztapalapa. Bases de datos SNIB-CONABIO. Proyecto No. P130. Ciudad de México, México .

Loy, A., M. L. Carranza, C. Cianfrani, E. D. Alessandro, P. Marzio, M. Di Minotti, And G. RegGiani. 2009. Otter Lutra lutra population expansion: assessing habitat suitability and connectivity in southern Italy. Folia Zoologica 58:309-326.

Marucco, F., D. Boitani, H. Pletscher, and M. K. Schwartz. 2010. Bridging the gaps between non-invasive genetic sampling and population parameter estimation. European Journal of Wildlife Research 57:1-13. 
Mason, C. F. 1995. Habitat quality, water quality and otter distribution. Hystrix (New Series) 7:195-208.

NOM-059-SEMARNAT-2010. 2010. Norma Oficial Mexicana. Protección ambiental-Especies nativas de México de flora y fauna silvestres-Categorías de riesgo y especificaciones para su inclusión, exclusión o cambio-Lista de especies en riesgo. Diario Oficial, Jueves 30 de diciembre de 2010.

Page, L. M. And B. M. Burr. 1991. A field guide to freshwater fishes of North America north of Mexico. Houghton Mifflin Company, Boston, U.S.A.

PARDINI, R. And E. TRAJANo. 1999. Use of shelters by the neotropical river otter (Lontra longicaudis) in an Atlantic forest stream, southeastern Brazil. Journal of Mammalogy 80:600-610.

Pearse, D. E. and K. A. Crandall. 2004. Beyond Fst : Analysis of population genetic data for conservation. Conservation Genetics 5:585-602.

Pedroso, N. M. and M. Santos-Reis. 2009. Assessing otter presence in dams: A Methodological proposal. IUCN Otter Spec. Group Bull 26:97-109.

Pohle, H. 1920. Die unterfamilie der Lutrinae. Archiv fur Naturgeschchte 85A:1-247.

Polechla, P. J., A. G. Burns, S. Rist, K. A. Moore, and J. W. Dragoo. 2004. First physical evidence of the Nearctic river otter (Lontra canadensis) collected in New Mexico, USA, since 1953. IUCN Otter Specialist Group Bulletin 21:70-75.

Polechla, P. J. and E. Carrillo-Rubio. 2009. Historic and current distributions of river otters (Lontra canadensis) and (Lontra longicaudis) in the Rio Grande or Rio Bravo del Norte drainage of the Colorado and New Mexico, USA, and Chihuahua, Mexico and adjacent areas. IUCN Otter Specialists Group Bulletin 26:81-95.

Rabinowitz, A. And K. A. Zeller. 2010. A range-wide model of landscape connectivity and conservation for the jaguar, Panthera onca. Biological Conservation 143:939-945.

Ramos-Rosas, N. N., C. Valdespino, J. García-Hernández, J. P. GalloReYNoso, And E. J. Olguín. 2012. Heavy metals in the habitat and throughout the food chain of the neotropical otter, Lontra longicaudis, in protected Mexican wetlands. Environmental Monitoring Assessment 185:1163-73.

Reid, N., D. Thompson, B. Hayden, F. Marnell, and W. I. Montgomery. 2013. Review and quantitative meta-analysis of diet suggests the Eurasian otter (Lutra lutra) is likely to be a poor bioindicator. Ecological Indicators 26:5-13

Rheingantz, M. L. ANd C. S. TrincA. 2015. Lontra longicaudis. The IUCN Red List of Threatened Species 2015: e.T12304A21937379. http://dx.doi.org/10.2305/IUCN. UK.2015-2.RLTS.T12304A21937379.en. Downloaded on 12 September 2016.

Sales-Luís, T., D. Freitas, and D. Santos-Reis. 2009. Key landscape factors for Eurasian otter Lutra lutra visiting rates and fish loss in estuarine fish farms. European Journal of Wildlife Research 55:345-355.

SÁnChez, O. And J. P. Gallo-Reynoso. 2007. Evaluación del riesgo de extinción de Lontra longicaudis de acuerdo al numeral 5.7 de la NOM-059-SEMARNAT-2001. Pp. 61-89 in Método de evaluación del riesgo de extinción de la especies silvestres en México (MER) (Sánchez, O., R. Medellín, A. Aldama, B. Goettsch, J. Soberón and M. Tambutti, eds.). SEMARNAT-INEIECUNAM-CONABIO. Ciudad de México, México.
SAntiago-Plata, V. M. 2013. Ocupación y distribución potencial de la nutria neotropical (Lontra longicaudis) asociada a variables ambientales en la cuenca del río San Juan, Costa Rica. Centro Agronómico Tropical de Investigación y Enseñanza 144.

Serfass, T., S. S. Evans, And P. Polechla. 2015. Lontra canadensis. The IUCN Red List of Threatened Species 2015: e.T12302A21936349 http://dx.doi.org/10.2305/IUCN.UK.20152.RLTS. T12302A21936349.en

Sexton, J. P., P. J. Mclntyre, A. L. Angert, and K. J. Rice. 2009. Evolution and Ecology of Species Range Limits. Annual Review of Ecology, Evolution, and Systematics 40:415-436.

Trewavas, E. 1982. Tilapias: taxonomy and speciation. Pp. 3-13 in The biology and culture of tilapias (Pullin, R. S. V., and R. H. Lowe-McConnell, eds.). ICLARM Conf. Proc. 7. (Ref. 1).

TrinCA, C. S., C. F. JAEGER, AND E. EIZIRIK. 2013. Molecular ecology of the Neotropical otter (Lontra longicaudis): non-invasive sampling yields insights into local population dynamics. Biological Journal of the Linnean Society 109:932-948.

Van Looy, K., J. Piffady, C. Cavillon, T. Tormos, P. Landry, and Y. SOUCHON. 2014. Integrated modelling of functional and structural connectivity of river corridors for European otter recovery. Ecological Modelling 273:228-235.

Waldemarin, H. F. and R. Alvares. 2008. Lontra longicaudis. In IUCN 2010. IUCN Red List of Threatened Species.

Walker, M., S. Johnsen, S. O. Rasmussen, J. P. Steffensen, T. Popp, P. Gibbard, W. Hoek, J. Lowe, S. Buörk, L. Cwynar, K. Hughen, P. Kershaw, B. Kromer, T. Litt, D. J. Lowe, T. Nakagawa, R. Newnham, AND J. SChWANDER. 2008. The Global Stratotype Section and Point (GSSP) for the base of the Holocene Series/Epoch (Quaternary System/Period) in the NGRIP ice core. Episodes 31:264-267.

Associated editor: Jorge Servín

Submitted: Julio 11, 2019; Reviewed: August 19, 2019;

Accepted:September 18, 2019; Published on line:September 23, 2019. 
NEARCTIC OTTER IN MEXICO

254 THERYA Vol. 10 (3): 243-253 